\title{
PERGESERAN LOKASI PEMUKIMAN ORANG CINA DI KOTA BANTEN DARI ABAD XVI - XIX (BERDASARKAN PENGAMATAN PETA KUNA KOTA BANTEN)
}

\author{
Oleh: Widya Nayati
}

Bekas Ibukota Kerajaan Banten saat ini terletak di Kalurahan Banten, Kecamatan Kasemen, Kabupaten Serang, Propinsi Jawa Barat. Kota Banten terletak di tepi Laut Jawa dan berada pada sebuah teluk yang bernama Teluk Banten. Tepatnya kota Banten terletak di antara dua muara sungai, yaitu muara sungai Cibanten Lama di sebelah timur dan muara anak sungai Cibanten Lama di sebelah barat kota. Kota Banten berfungsi sebagai Ibukota kerajaan Banten dari tahun 1552 hingga 1813.

Kota Banten sebagai pusat pemerintahan kerajaan Banten terletak di jalur pelayaran internasional (Uka Tjandrasasmita, 1977; Manguin P.Y, 1983). Hal ini berakibat kota Banten menjadi tempat persinggahan : $:$ ra pedagang dari berbagai bangsa. Para pelayar yang biasanya juga berfungsi sebagai pedagang itu, singgah di pelabuhan untuk memenuhi kebutuhan bagi perjalanan selanjutnya. Kebutuhan yang diperlukan dalam setiap pelayaran antara lain berupa bahan makanan, kayu bakar dan air minum (Sutjipto Tjiptoatmojo, 1983 : 49). Selain itu para pedagang -pelaut tersebut juga memanfaatkan waktu persinggahannya untuk menjual barang dagangan yang dibawa, serta membeli barang- 
barang yang ada di pasar lokal untuk diangkut ke daerah lain ataupun ke daerah asalnya.

Secara geografis pelabuhan Banten terletak di suatu teluk yang memungkinkan kapal terhindar dari angin siklon ataupun badai. Daya tarik pelabuhan Banten yang lairı ialah kemudahan kapal-kapal untuk berlabuh dan merapat di tepi daratan, bea cukai yang dianggap wajar oleh para pedagang-pelaut, tersedianya kebutuhan bagi pelayaran dan adanya fasilitas perdagangan yang memadai.

Salah satu bentuk fasilitas untuk 'serdagang adalah pasar. Willem Lodewycksz menyebutkan bahwa di kota Banten terdapat tiga buah pasar yaitu di Karangantu, pasar Paseban dan pasar Pacinan (Uka Tjandrasasmita, 1977 : 117-118). Catatan Belanda lainnya menambahkan bahwa bentuk pasar di Banten berupa bangunan los beratap. (Berg, 1939:328). Sedangkan pedagang yang pernah datang ke Banten antara lain orang-orang dari Cina, Gujarat, India, Bengala, Malabar, Keling, Persia, Arab, Portugis, Belanda, Turki, Malaka dan orang-orang dari berbagai kawasan di Indonesia (Uka Tjandrasasmita,|1977:121 - 129; Berg, 1939:329).

Para pedagang dari berbagai bangsa yang singgah di Banten ada yang tinggal menetap dan ada pula yang tinggal pada saat-saat tertentu saja. Adanya orang yang tinggal menetap di kota Banten mengakibatkan adanya pengelompokan pemuhıman, terutama berdasarkan asal bangsa, misalnya kelompok pemukiman orang Cina (yang biasa disebut sebagai Pecinan/Pacinan), kelompok pemukiman bangsa yang berasal dari Asia Barat (Pekojan), kelompok pemukiman orang-orang Belanda dan kelompok pemukiman Inggris.

Kedatangan pedagang-pelaut di kota Banten dan menetapnya para pedagang-pelaut tersebut mengakibatkan kota Banten menjadi kota yang s ramai dan penduduknya semakin meningkat. Penduduk Banten tahun 1680 diduga oleh Fryke berjumlah 700 ribu jiwa. Perkiraan ini berdasarkan atas perbandingan dengan kota-kota sejaman di Asia Tenggara lainnya (Reid, 1980:237-238). Pada tahun 1694 jumlah penduduk di 
Banten menjadi 31.848 jiwa, sedangkan penduduk Banten tahun 1708 berjumlah 36.302 jiwa. Perhitungan jumlah penduduk di Banten tahun 1694 dan 1708 lebih akurat, karena dilakukan dengan sensus penduduk. (Uka Tjandrasasmita, 1977:169). Pada awal abad XVIII penduduk Banten diperkirakan oleh Francois Valentijn berjumlah 30 ribu hingga 40 ribu jiwa. ( Uka Tjandrasasmita, 1977: 171).

Pertambahan jumlah penduduk yang pesat di kota Banten diduga merupakan faktor penyebab adanya perkembangan kota Banten. Berdasarkāin pengarmatan peta kuna kota Banten tahun 1596, 1624, 1726, $1739,1825,1826$, dan 1900, gambaran tentang pertambahan jumlah pemukiman dapat diketahui. Sekitar abad XVI jumlah pemukiman diduga hanya sembilan buah, tetapi hingga abad XIX jumlah pemukiman yang ada di Banten menjadi 46 buah. Kota Banten yang telah berkembang dari intinya ini kemudian sering disebut dengan Surasaji atau Surasowan. (Graaf dan Pigeaud, 1985 (terj): 151, 153).

Dari peta kuna kota Banten dapat diketahui pula adanya perkembangan pendirian bangunan yang ada di kota Banten. Hasil kegiatan pembangunan yang dilakukan kerajaan Banten selama tiga abad masih dapat dilihat sisanya hingga kini. Sisa kegiatan pembangunan kota Banten adalah (1) benteng kraton Surasowan dan sisa kegiatan di kraton Surasowan, (2) reruntuhan kraton Kaibon, (3) Benteng Speelwijk, (4) Masjid Agung Banten, (5) menara dan mihrab Masjid Pacinan Tinggi, (6) reruntuhan Masjid Pekojan, (7) klenteng Avalokiteswara, (8) danau Tasikardi. Dari delapan sisa bangunan masa kekayaan kerajaan Banten tersebut, bangunan yang masih berfungsi hingga kini hanyalah Masjid Agung Banten dan klenteng Avalokiteswara.

Diketahui pula melalui peta bahwa terdapat pengelompokan pemukiman berdasarkan ras, yaitu kelompok pemukiman orang Cina, Gujarat, Belanda, dan Inggris. Selain itu dapat diketahui pula adanya pergeseran lokasi suatu pemukiman.

Pergeseran lokasi pemukinnan di suatu kota merupakan masalah yang menarik. Untuk itu pada tulisan ini akan dibahas tentang pergeseran pemukiman yang ada di Banten. Pemukiman yang akan dibahas adalah 
pemukiman orang-orang Cina dari abad XVI $-X I X$. Pada tulisan ini hanya akan diamati pergeseran lokasi pemukiman orangg-orang cina dari peta kuna, dan tidak akan membahas tentang alasan dan sebab adanya pergeseran pemukiman tersebut.

Salah satu kelompok etnis yang berperan dalam perkembangan kota Banten adalah kelompok etnis Cina. Pada mulanya para pedagang Cina ikut ambil bagian dalam perdagangan rempah-rempah di pelabuhan Banten. (Graaf \& Pigeaud, 1985 (terj): $\quad$ ). Perdagangan rempahrempah di pasar Banten sangat ramai, karena barang dagangan tersebut selain dibawa oleh pedagang dari bagian timur Indonesia, juga karena Banten dan daerah kekuasaannya adalah penghasil komoditi ini. (Graaf \& Pigeaud, 1985:151).

Dalam perkembangannya, para pedagang Cina ternyata ada yang menetap di kota Banten berkumpul menjadi satu kelompok pemukiman. Kelompok pemukiman orang-orang Cina sering disebut Pecinan. Data tentang pemukiman Cina di Banten dapat diperoleh dari peta kuna kota Banten tahun 1596, 1624, 1726, 1825- 1826 dan 1900.

Adanya pemukiman Cina di kota Banten sekitar akhir abad XVI dapat diamati berdasarkan peta kota Banten tahun 1596. Pada peta tersebut digambarkan pemukiman orang-orang Cina terletak di sebelah luar sudut barat laut kota Banten. Letak pemukiman tersebut di sebelah barat muara anak sungai Cibanten di tepi Laut Jawa. Di dalam peta digambarkan bahwa Kampung Pecinan dikelilingi pagar kayu (?) dengan pintu gerbang menghadap ke arah Laut Jawa. Letak pemukiman ini di luar kota Banten. Hal ini didasarkan atas pengamatan bahwa pemukiman tersebut terletak di luar tembok kota Banten yangsberbentuk zigzag.

Sekitar tahun 1624, ternyata pemukiman Pecinan telah bergeser lokasinya ke arah pedalaman. Daerah yang pada tahun 1596 digunakan 
sebagai perkampungan Pecinan, beralih menjadi pemukiman bagi para nelayan. Keterangan tentang pergeseran lokasi pemukiman Pecinan dan penggunaan lokasi Pecinan yang berada di tepi pantai diperoleh melalui peta kota Banten tahun 1624.

Lokasi Pecinan sekitar tahun 1624 tepatnya berada di sebelah luar sudut barat daya kota Banten. Pemukiman Pecinan ini, juga terletak di luar tembok kota Banten yang beroentuk zigzag. Dari peta diinterpretasikan bahwa Pecinan telah memiliki penataan pemukiman dan juga jalan darat.

Lokasi kampung Pecinan yang terletak di sudut barat daya kota Banten ternyata masih digunakan hingga sekitar tahun 1659. Dari peta tahun 1659, diketahui lebih jelas bahwa jalan yang terdapat di Pecinan dibuiai dari batu. Keterangan tentang letak Pecinan yang berada di luar tembok kota Banten diperkuat dengan keterangan yang diperoleh dari peta tahun 1659 ini. Pada legenda peta disebutkan bahwa letak pemukiman Pecinan berada di dekat pagar. Kemungkinan yang dimaksud dengan pagar adalah tembok kota Banten. Letak Pecinan yang berada di luar tembok kota Banten ternyata tidak merupakan kesulitan bagi para pemukimnya. Sebab antara Pecinan dengan pemukiman di dalam tembok kota terdapat sarana penghubung berupa jalan dan pintu gerbang yang terletak di tembok kota Banten sisi barat.

Pemukiman Pecinan di sudut barat daya Banten ternyata masih berlangsung hingga sekitar tahun 1726 . Hal ini didasarkan atas pengamatan terhadap kota Banten tahun 1726 yang dibuat oleh Francois Valentijn. Namun dari peta tahun 1726 tidak dapat diketahui keadaan pemukiman orang-orang Cina sekitar tahun tersebut. Hal ini disebabkan karena legende peta tahun 1726 sangat sulit untuk dibaca.

Dari pengamatan peta kota Banten tahun 1825 - 1826 dan tahun 1900 dapat ditunjukkan bahwa pemukiman orang Cina tidak lagi terletak di pedalaman (sudut barat daya kota Banten), akan tetapi terletak di pertengahan antara dua lokasi Pecinan sebelumnya. Pada peta $1825-$ 1826 dan 1900 disebutkan adanya kampung Cina dan masjid Pecinan 
Tinggi di lokasi yang dimaksud. Tetapi keadaan Pecinan yang berada di tengah-tengah sisi barat kota Banten tidak dapat diketahui, sebab kedua peta tersebut tidak menggambarkan pemukiman Pecinan dengan terperinci.

Pemukiman Pecinan di kota Banten seperti yang digambarkan pada peta tahun 1825 - 1826 dan 1900, ternyata hingga kini tetap dipertahankan. Hanya saja, yang tinggal di kampung Pecinan sekarang tidak seluruhnya orang-orang cina.

III

Dari bahasan di atas dapat disimpulkan bahwa lokasi pemukiman orang-orang Cina di kota Banten dari abad XVI hingga XIX mengalami pergeseran lokasi. Mula-mula Pecinan terletak di tepi muara dan laut, kemudian bergeser ke arah pedalaman hingga sekitar tahun 1726, dan akhirnya hingga sekarang lokasi Pecinan terletak di pertengahan sisi barat kota Banten.

Selain itu, diketahui pula bahwa ke tiga lokasi Pecinan di Banten dari abad XVI hingga XIX selalu berada di luar tembok kota Banten. Lokasi pemukiman Pecinan selain dibatasi sisi timurnya oleh tembok kota Banten yang berbentuk zigzag, juga oleh aliran anak sungai Cibanten yang bermuara di kampung Pabean. Letak Pecinan yang di luar tembok kota ternyata tidak mengakibatkan terputusnya hubungan antara pemukiman di dalam dan di luar tembok kota karena terdapat sarana untuk menghubungkan keduanya.

Adanya pergeseran lokasi Pecinan di kota Banten ternyata diperkuat oleh data arkeologis. Bekas pemukiman cina yang dahulu terletak di tepi laut Jawa ditunjukkan oleh adanya bangunan berupa klenteng Avalokiteswara. Memang masih merupakan tanda tanya tentang kapan berdirinya klenteng Avalokiteswara ini. Menurut tradisi, klenteng ini dibangun pada awal kerajaan Banten (Mundarjito, 1978:6). Akan tetapi berdasarkan interpretasi tentang peta Banten tahun 1624, 1659 dan 1726 
nampak bahwa klenteng Avalokiteswara telah digambarkan pada peta tersebut. Lokasi bekas Pecinan tersebut sekarang sudah tidak di tepi Laut Jawa. Hal ini dimungkinkan karena adanya pengendapan pantai utara Banten yang relatif cepat, sehingga daratan utara Banten menjadi semakin luas.

Dari bekas pemukiman orang cina di sudut barat daya kota Banten sangat sedikit data yang diperoleh, yaitu hanya berupa makam Cina yang jumlahnya juga tidak banyak. Hal ini memang sangat kontradiktif karena lokasi sudut barat daya dihuni paling lama yaitu sejak sekitar tahun 1624 hingga sekitar 1726 . Tentunya penelitian yang intensif di lokasi yang diduga sebagai bekas Pecinan di sudut barat daya kota Banten tersebut akan dapat menjawab masalah ini.

Di selatan klenteng, yaitu pada lokasi pecinan yang digunakan pada sekitar tahun 1825-1826 hingga sekitar 1900, masih dijumpai rumah dengan arsitektur Cina. Sampai dengan saat ini rumah tersebut dihuni oleh keluarga nelayan Cina. Data lainnya yang dapat diperoleh di lokasi pecinan ini ialah adanya menara masjid dan mihrab masjid Pecinan Tinggi, makam Cina dan juga nama kampung. Di sekitar daerah ini sering ditemukan pula nisan Cina dari bahan pualamyang sekarang telah berubah fungsinya.

Dari bahasan di atas, diketahui bahwa lokasi pemukiman orang-orang Cina yang tinggal di Banten terletak di luar tembok kota Banten. Selain itu, selama tiga abad, ternyata pemukiman Pecinan telah mengalami pergeseran. Namun latar belakang bergesernya lokasi Pecinan masih perlu penelitian lebih lanjut. 


\section{DAFTAR PUSTAKA}

Berg, C.C. et. al. 1933. Geschiedenis van Nederlandsch Indie, deel II Amsterdam: Jost van den Vondel.

Chijs, J.A. van der. 1881. "Oud Bantam", TBG, XXVI, halaman 1-62.

Cortesao, Armando. 1944. The Suma Oriental of Tome Pires, vol. I, London The Hakluyt Society.

Graaf. H.J. en Th. G. Th. Pigeaud, (terj. Javanologi). 1985. Kerajaankerajaan Islam di Jawa Peralihan dari Majapahit ke Mataram, Jakarta: Grafitipers.

Ijzerman, J.W. 1923. Cornelis Buijsero te Bantam 1616-161-S zijn Brieven en Journal. 's-Gravenhage: Martinus Nijhoff.

Manguin, Piere-Yves. 1983. "Dunia yang Ramai: Laut Cina dengan Jaringan-jaringannya". Citra Masyarakat Indonesia, Jakarta: Sinar Harapan dan Archipel.

Mundarjito, dkk. 1978. "Laporan Penelitian Arkeologi Banten 1976", BPA, nomor 18, Jakarta: P.T. Rora Karya.

Reid, Anthony. 1980. "The Structure of Cities in Southeast Asian, Fiftteenth to Seventeenth Century", Journal of Southeast Asian Studies, vol XI, no. 2, September, halaman 235-250.

Roelofsz, Meilink. 1963. Asian Trade and European Influence in the Indonesian Archipelago Between 1500-1630. The Hague: Martinus Nijhoff. 
Serrurier, L. 1902. Kaart van Oud Banten (Bantam), Batavia: Albrecht and Co.

Sutjipto Tjiptoatmidjo. 1983. "Kota-kota Pantai di Sekitar Selat Madura (Abad XVII sampai medio abad XIX), disertasi, UGM.

Uka Tjandrasasmita (ed). 1977. Sejarah Nasional Indonesia III, Jakarta: Balai Pustaka.

Wall, V.I. van de. 1881. "Oud Batam", TBG, XXVI.

Widya Nayati 1985. "Telah Arkeologi Pada Kota Banten Lama Berdasarkan interpretasi Foto udara, Thesis sarjana Jurusan Arkeologi Fakultas Sastra UGM. 


\section{PETA KOTA BANTEN TH. 1595}

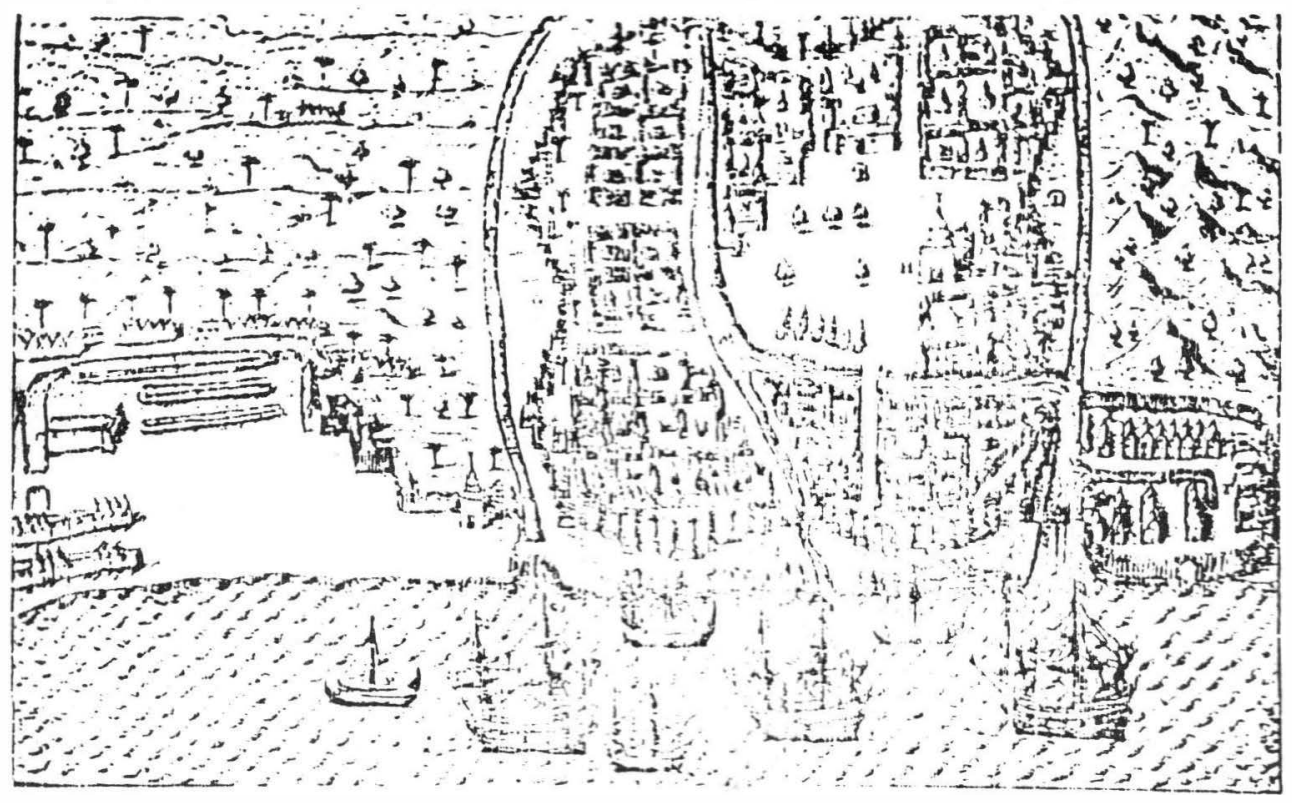

Keterangan:

A keraton sultan

B paseban

C : gerbang daratan

D gerbang gunung

$E$ gerbang laut

$F$ gerbang kisi-kisi

G menara

E Mesjid Agung Banten

I : perkampungan orang-orang Cina

L tempat tinggal Pangeran Gebang

$M$ : sungai Cibanten
$\mathrm{N}$; istana syahbandar

$\mathrm{O}$ : istana laksamana

$P$ : istana Ceti Maluku

$Q$ : istana kakaknya gubernur

$\mathrm{R}$ : istana senopati

S istana Ngabehi Panjang Jiwa

$\mathrm{T}$ : pasar orang-orang cina

$\mathrm{V}$ : istana Andemoin

$X$ : penginapan penyewa gudang

$Y$ : perumahan orang-orang Gujarat dan Bengal

$Z$ : gudang senjata 


\section{PETA KOTA BANTEN TAHUN 1624}

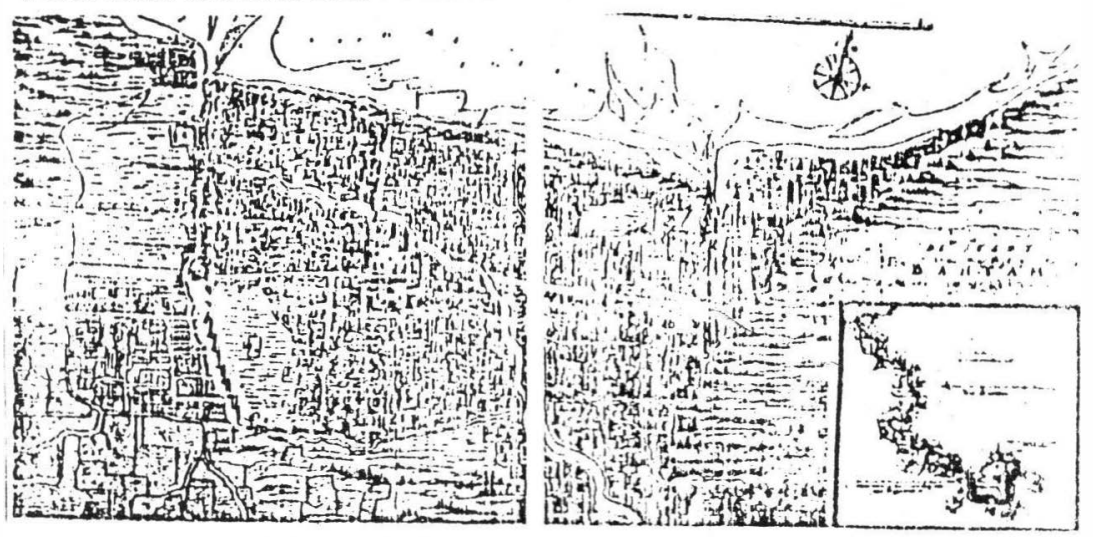

Keys to maps on left hand page

\section{THE CITY OF BANTAM}

(Banten) - c.. 1624

Translation of Original Key:

A. The King's Court; Bv. The Principal Temple; C. The Small Passer (pasar) or Market; D. The Sheds for the King's Principal War Prahus: E. The King's Elephant House; F. The Place for the King's guns, which he used in his defensive works which he made during the most recent siege of Bantam being in als 14 diverse pieces mostly provided with interior our-carriages; G The King's Balai or Sitting places, and the trees where he ordinarily hoids his Council meetings; $\mathrm{H}$. Dwelling of a great Nobleman being close in blood to the King; Y. Is the great Passer, or daily Market, with houses and gardens in and round about it. In the vicinity of when is also the best landing-place and the least defence.

Translation of Dutch descriptions on the map itself.

Top left. Fishermen's Quarters

Lower left, outside walls This $10 \mathrm{~A}$ wall ras deliver the Chinese Quarter since ancient times

Inset, lower right: The detailed aignment of the river of Bantam aa The English washing place, where the river is ordinatily om, 2 or 3 feel deep and thoroughly rocky

$\mathrm{BB}$. The old washing place of the Netherlanders 


\section{SKETSA KOTA BANTEN TAHUN 1659}

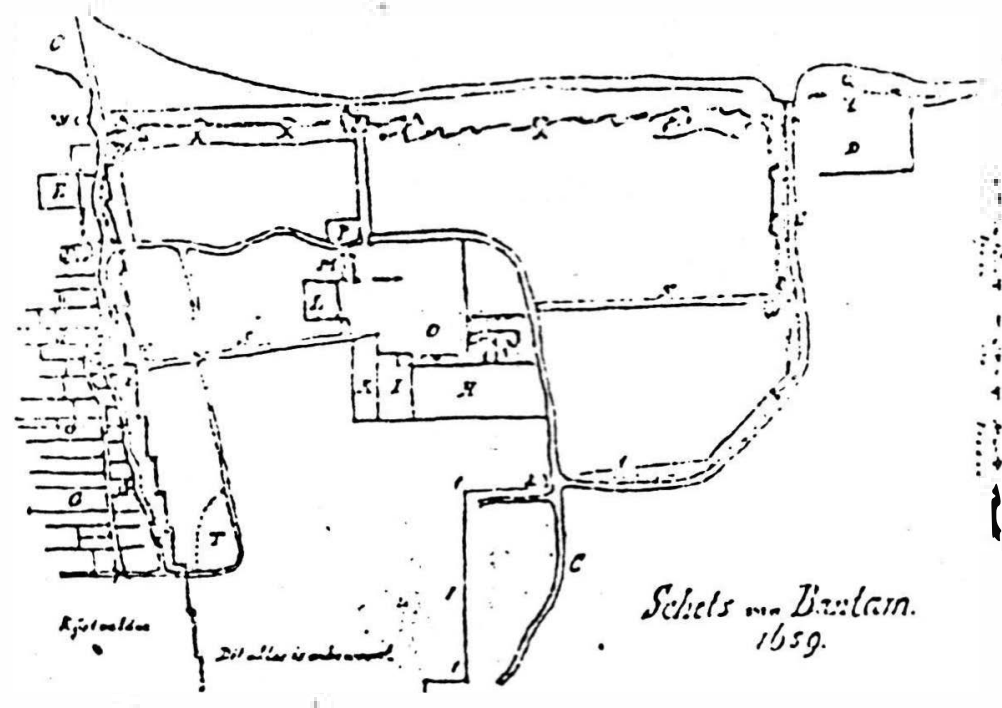

\section{Keterangan:}

A. Bangunan setinggi dua meter. untuk menembak ke arah laut. Dijelaskan bahwa ba ngunan tersebut telah rusak.

B. Merupakan tembok baru. Sepanjang sungai terdapat pintu gerbang. Dijelaskan oleh van Bur. bahwa tembok ini dibuat rangkap seperti tembok kota lainnya. Akan tetapi tembok ini telah rusak. Tembok banyak yang tidak berlepa karena huian dan banyak pintu yang tidak berdaun pintu.

C. Di sebeiah timur sungai. daerahnya berpasir hingga Pontang. Sungai tersebut apabila berair dapat dilayari hingga ke laut. Di daerah ini ada pulau yany namanya puiau Dod. Antara pulau Doa dan Pontang terdapat daerah tinggi yang berpasir.

D. Pasar besar. yang pada pagi hari menjual bermacam-macam barang. antara lain baju tenun yang dibuat oleh orang Cina dan Jawa. Di sisi utara. terdapat tembok yang diperkuat dengan $10-12$ batang besi.

E. Pemukiman orang-orang Inggris yang kemungkinan mempunyai tembok dari batu.

F. Kemungkinan pemukiman Belanda. Bagian bertembok batu. sedangkan di bagian beiakang berpagar bambu. 
G. Merupakan jalan pemukiman Cina yang dibuat dari batu. letaknya di dekat pagar.

H. Kraton, yang di dalamnya terdapat gudang senjata.

I. Rumah Pangeran Madura.

K. Rumah pangeran Lor saudara raja.

L Masjid dan menara. Menara lebih tinggi dari pohon yang ada di sekitarnya.

M. Gudang beras (dalam keadaan belum selesai).

N. Rumah Kyai Aria

Q. Alun-alun, terdapat pohon yang berpagar tembok.

P. Rumah Kyai.

Q. Daerah yang saat itu digunakaan sehagai pemukiman orang Mataram. Dijelaskan bahwa mereka boleh menyeberangi sungai (untuk ke dalam kota T)

R. Rumah-rumah ada yang denyan bambu.

S. Jalan dengan rumah bambu dan pagar-pagar yang teratur

T. Tempat membuat barang dari tanah liat.

$V$. Daerah yang selalu kering, walaupun air sedang pasang.

$W$. Rumah jaga yang mampu menampung $2-3$ orang.

$X$. Daerah rendah.

Y. Tembok dari batu putih. Tembok ini masih baru.

Z. Gudang Garam.

1. Tembok

2. Tembok yang dapat menembak ke arah sungai. 


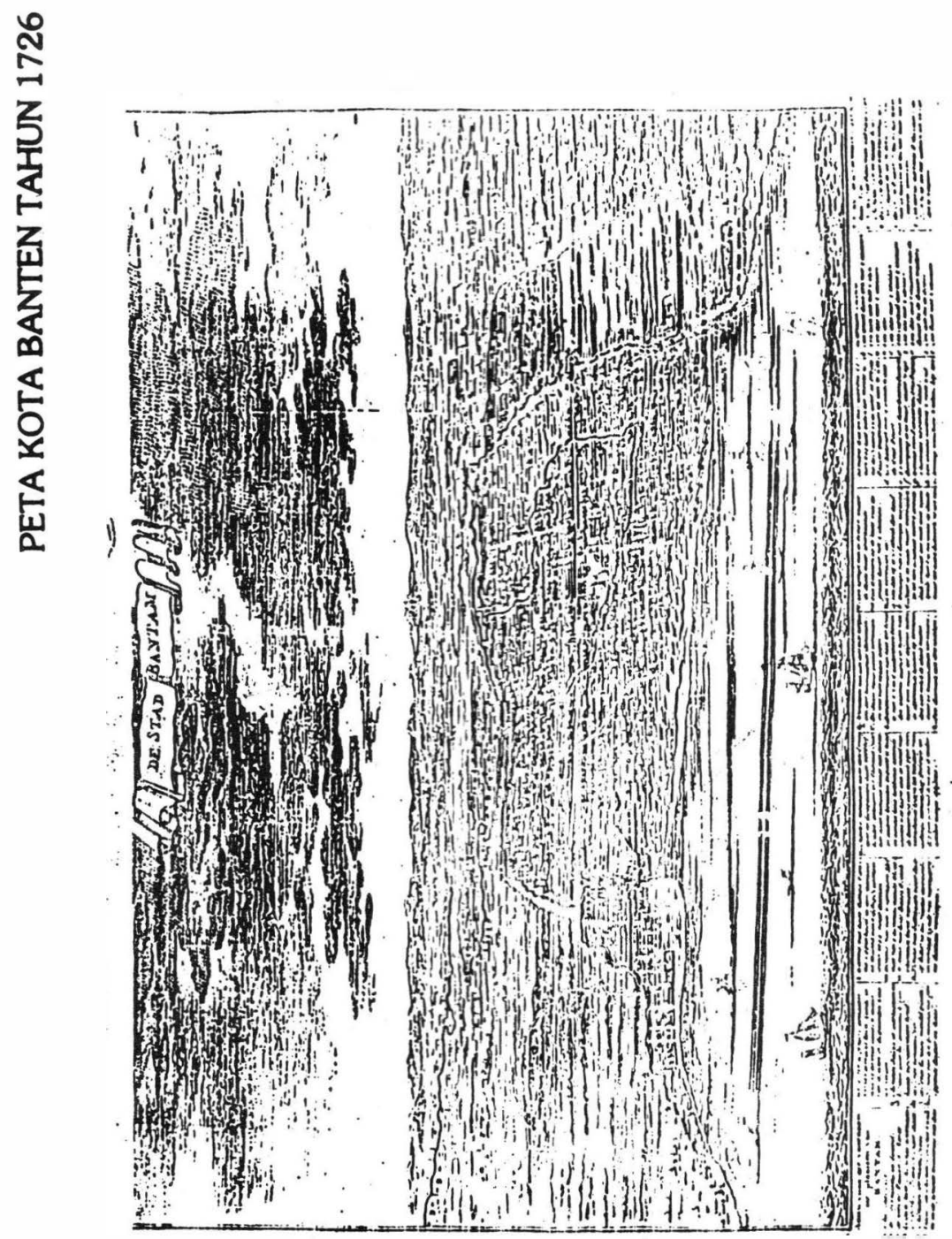

